\title{
Anthelmintic Evaluation of Some Novel Synthesized 1,2,4-Triazole Moiety Clubbed with Benzimidazole Ring
}

\author{
P. SUDHIR KUMAR ${ }^{1 *}$ and J. SAHOO \\ ${ }^{1}$ School of Pharmaceutical Sciences, Department of Pharmaceutical Chemistry, \\ Siksha 'O' Anusandhan University, Bhubaneswar, Odisha - 751 003, India. \\ ${ }^{2}$ Research Scholar, School of Pharmaceutical Sciences, Siksha 'O' Anusandhan University, \\ Bhubaneswar, Odisha - 751 003, India. \\ ${ }^{\star}$ Corresponding author E-mail: sairampaidesetty @ gmail.com \\ http://dx.doi.org/10.13005/ojc/300125 \\ (Received: January 25, 2014; Accepted: March 03, 2014)

\begin{abstract}
A series of $\mathrm{N}$-[3-\{(1H-benzo[d]imidazol-2-ylthio) methyl\}-5-mercapto-4H-1, 2, 4-triazol-4$\mathrm{yl}]$-2-substituted phenoxy acetamide $6(\mathrm{a}-\mathrm{g})$ were synthesized by the mixture of the compound of potassium 2-(2-(1H-benzo[d]imidazol-2-ylthio) acetyl) hydrazinecarbodithioate (4) and aryloxy acid hydrazide (5) in presence of hydrochloric acid. The predicted structures of the synthesized compounds were confirmed by different spectral analysis studies. The title compounds $6(\mathrm{a}-\mathrm{g})$ were screened for anthelmintic activity against Pheretima posthumous. The entire compounds were exhibited good anthelmintic activity when compared with standard drugs such as Albendazole and Piperazine.
\end{abstract}

Key words: 5-mercapto-1, 2, 4-triazoles, Anthelmintics activity, Aryloxy substituted phenoxy acetic acid, 2-merkapto benzimidazole.

\section{INTRODUCTION}

There are two important types of worm infections, those in which the worms live in the alimentary canal of the host and worms live in other tissues of the host body. Common examples of worms $^{1}$ in the alimentary canal are the tapeworm, intestinal round worm, trematodes or flukes, tissue round worm and diseases caused by helminthes are ascariasis, trichirians, hook worm and tape worm infection, thread worm infection, schistosomiasis and giardial infection ${ }^{2}$. During the last decades the compounds bearing heterocyclic nuclei have received much more attention due to their medicinal value in the development of novel anthelmintics drugs. Benzimidazole derivatives have been a wide range of biological activities, such as analgesic ${ }^{3}$, antiinflammatory ${ }^{4}$, antiparasitic ${ }^{5}$, antitubercular ${ }^{6}$, antiviral ${ }^{7}$, anticonvulsant ${ }^{8}$ and antimicrobial activities ${ }^{9}$ 10. Literature survey indicated that the compounds consists of 1,2, 4-triazole ring have been reported to possess different biological activities such as antimicrobial $^{11}$, antifungal ${ }^{12}$, anti-inflammatory ${ }^{13}$, antioxidant $^{14-15}$, antiviral ${ }^{16}$, anticancer ${ }^{17}$ and 
anticonvulsant activity ${ }^{18}$ depending on the substituent in the ring system. In view of such biological reports, the present work is aimed to design and develop the synthesis of some new potential substituted aryloxy triazolyl Benz[b] imidazole moiety and explores the evaluation of their in-vitro anthelmintic activity.

\section{EXPERIMENTAL}

The chemicals and solvents used for the experimental work were procured from E. Merck, India, and Qualigens, India. Silica gel G used for analytical chromatography (TLC) was obtained from E. Merck. Melting points were determined in an open glass capillary using a Kjeldahl flask containing paraffin and are uncorrected. The proton magnetic resonance spectra ( $\left.{ }^{1} \mathrm{H} \mathrm{NMR}\right)$ were recorded on a Bruker $300 \mathrm{MHz}$ instrument (Bruker, Germany) in dimethylsulfoxide- $d_{6} / \mathrm{CDCl}_{3}$ using tetramethylsilane as internal standard. Chemical shifts $(\delta)$ are expressed in $\mathrm{ppm}$. The infrared spectra of compounds were recorded in $\mathrm{KBr}$ on infrared spectrophotometer Jasco, Japan. Purity of the compounds was checked by TLC using silica gel $\mathrm{G}$.

\section{Preparation of 2-mercapto Benzimidazole (1)}

A mixture of o-phenylenediamine $32.4 \mathrm{gm}$ (0.3mole) potassium ethyl xanthate $52.8 \mathrm{gm}$ ( $0.33 \mathrm{~mole}), 95 \%$ ethanol $300 \mathrm{ml}$ and $45 \mathrm{ml}$ of water in a 1-1, flask was heated under reflux for 3 hours. Noritz (12gm) was then added cautiously and the mixture was heated at the reflux temperature for 10 minutes. Then Noritz was removed by filtration, the filtrate was heated to $60-70{ }^{\circ} \mathrm{C}, 300 \mathrm{ml}$ of warm tap water $\left(60-70{ }^{\circ} \mathrm{C}\right)$ was added followed by $25 \mathrm{ml}$ of acetic acid in $50 \mathrm{ml}$ of water with stirring. The product separated out as glistening white crystal and the mixture was placed in a refrigerator for 3 hours to complete the crystallization. The product is collected on a Buchner funnel dried overnight at $40^{\circ} \mathrm{C}$. Yield $86 \%$, m.p $303-304^{\circ} \mathrm{C}$.

\section{Preparation of Ethyl 2(Benzimidazolylthio) acetate (2)}

A mixture of 2-mercaptobenzimidazole (0.1mole), ethylchloroacetate $(0.1 \mathrm{~mole})$ and potassium carbonate $(0.1 \mathrm{~mole})$ and acetone (distilled) was taken in a round bottom flask and refluxed for 6-7 hrs. After the completion of reaction, the mixture was cooled at room temperature and then it was poured into the ice cold water. The solid obtained was filtered. Yield $63 \%$, m.p .208 ${ }^{\circ} \mathrm{C}$.

Preparation of 2-(benzimidazolylthio) acetic acid hydrazide (3)

To above ester dissolved in appropriate quantity of ethanol $(25 \mathrm{ml})$ hydrazine hydrate $(0.1 \mathrm{~mole}, 5 \mathrm{ml})$ was added and refluxed for $15 \mathrm{hrs}$. The mixture was kept for 10-12 hours at room temperature, solid obtained was filtered. Yield $62 \%$, m. p. $236^{\circ} \mathrm{C}$.

Preparation of potassium 2-[2-(1H-benzo[d] imidazol-2-ylthio) acetyl] hydrazinecarbodithioate (4)

A mixture of 2-(benzimidazolylthio) acetic acid hydrazide $(0.01 \mathrm{~mole})$ and $(0.01 \mathrm{~mole}, 1.60 \mathrm{~g})$ of potassium salt was taken in a round bottom flask and $50 \mathrm{ml}$ ethanol was added and refluxed for 8-10 hours and further diluted with ether $(30 \mathrm{ml})$. The separated solid was filtered, washed with ether, dried and used directly for the next step without further purification.

\section{Synthesis of Substituted Aryloxy hydrazide 5(a-g)}

The substituted acid ( 0.1 mole) and ethanol $(50 \mathrm{ml})$ were taken with a few drops of concentrated sulfuric acid and it was refluxed for 6 hours. The reaction mixture was concentrated by distilling of the excess of ethanol under reduced pressure and treated with a saturated solution of sodium bicarbonate. The ester obtained used for the preparation of hydrazide directly. The ester $(0.1 \mathrm{~mole})$ was dissolved in appropriate quantity of ethanol and to this hydrazine hydrate $(0.1 \mathrm{~mole})$ was added. The reaction mixture was taken in a round bottomed flask and refluxed for a period of 12-18 hours. Excess of ethanol was distilled off under reduced pressure. It was then poured into ice cold water and the solid obtained was filtered. It was crystallized from ethanol.

Preparation of 3, 4-disubstituted-5-mercapto-1, 2, 4-triazoles 6(a-g)

A mixture of the compound potassium 2-(2-(1H-benzo[d]imidazol-2-ylthio) acetyl) hydrazinecarbodithioate (4) and aryloxy acid hydrazide $5(\mathrm{a}-\mathrm{g})$ were heated in equimolar proportion in an oil bath at $160-180^{\circ} \mathrm{C}$.for 5-6 hours when profuse evolution of hydrogen sulphide was observed. The reaction mixture was cooled and diluted with ice 
cold water. On acidification with hydrochloric acid, the compound was obtained. It was filtered, washed with water and crystallized from aqueous ethanol $(80 \%)$.

\section{Anthelmintic activity}

The newly synthesized compounds were tested for anthelmintic activity ${ }^{19}$ against Pheretima posthumous (earth worms collected from Ekahabaor Botanical Garden, Near to Regional plant Resource Centre, Bhubaneswar, Odisha, India) of nearly equal size $(6 \pm 1 \mathrm{~cm})$ were selected randomly for the experimental study. The worms were acclimatized to laboratory conditions before experimentation. The earthworms were divided into four groups of six earth worms each. Albendazole and Piperazine citrate diluted with normal saline solution to obtain $0.1,0.2$, 0.5 and $1 \mathrm{mg} / \mathrm{mL}$ act as standard and were poured into Petri dishes. The synthesized compounds were dissolved in water and add minimal quantity of Tween 80 and make to prepare four concentrations of 0.1 ,
$0.2,0.5$ and $1 \mathrm{mg} / \mathrm{mL}$ of each compound in form suspension. Normal saline served as a control. The time taken for complete paralysis and death was noted. The mean paralysis time and mean lethal time were calculated for each compound (each reading was taken in triplicate). Paralysis was considered when no movement was observed even after shaken vigorously. Death was considered when the worm loss their motility followed by change in body color. Statistically analysis was performed using ANOVA to find the significance of the test.

6a.N-[3-\{(1H-benzo[d]imidazol-2-ylthio)methyl\}5-mercapto-4H-1,2,4-triazol-4-yl]-2-phenoxy acetamide

IR (KBr) cm-1: $3315(\mathrm{NH}), 3050-2910$ (C-H str., aromatic and aliphatic), $1150 \mathrm{C}=\mathrm{S}, 1660$ (CO of CONH), $1605(\mathrm{C}=\mathrm{N}), 1500$ (C-N), 845 (Substituted benzene), ${ }^{1} \mathrm{H}$ - NMR $\left(\mathrm{CDCl}_{3}\right) \delta: 6.95-7.59(\mathrm{~m}, 9 \mathrm{H}$, Ar-H), 10. 4(s, 1H,N-H),8.22 (1H,CONH), 4.62 $\left(\mathrm{d}, 2 \mathrm{H}, \mathrm{S}-\mathrm{CH}_{2}\right)$.

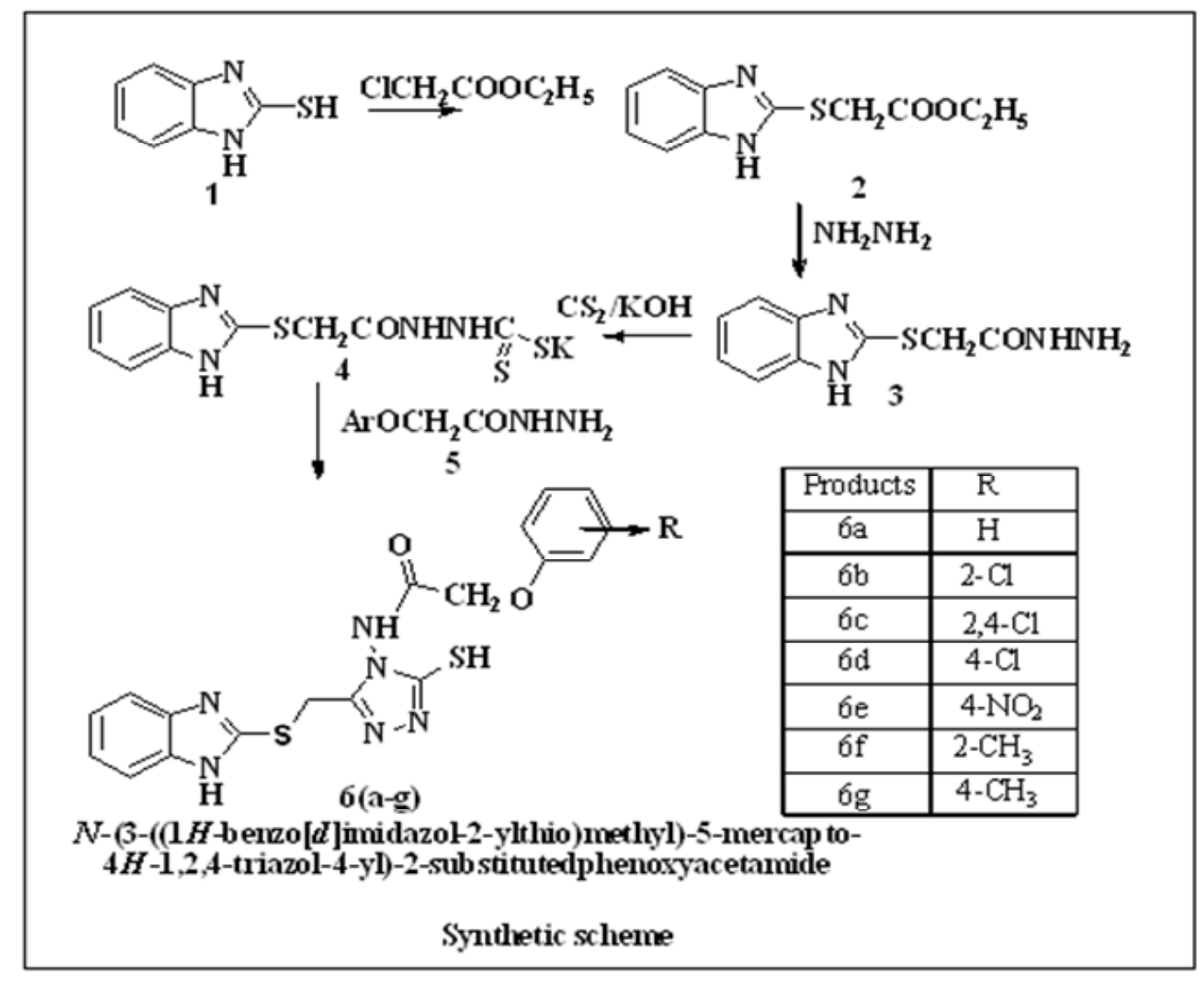


6b. $\mathrm{N}-[3-\{(1 \mathrm{H}-$ benzo[d]imidazol-2-ylthio $)$ methyl)-5-mercapto-4H-1, 2, 4-triazol-4-yl\}-2-(2chlorophenoxy)] acetamide

IR (KBr) cm $\mathrm{cm}^{-1}$ :3310(NH), 2950-2910 (C-H str., aromatic and aliphatic), $2550(\mathrm{SH})$ or 1175 $\mathrm{C}=\mathrm{S}, 1664$ (CO of CONH), $1615(\mathrm{C}=\mathrm{N}), 1500(\mathrm{C}-\mathrm{N})$, 650(C-Cl), 835(o-disubstituted benzene), ${ }^{1} \mathrm{H}-\mathrm{NMR}$ $\left(\mathrm{CDCl}_{3}\right)$ 8: 6.95-7.59 (m, 8H, Ar-H), 10. 35 (s, $1 \mathrm{H}$, $\mathrm{N}-\mathrm{H}), 8.12(1 \mathrm{H}, \mathrm{CONH}), 4.65$ (d, 2H, S- $\left.\mathrm{CH}_{2}\right)$.

6c. $\mathrm{N}-[3-\{(1 \mathrm{H}-$ benzo[d $]$ imidazol-2-ylthio $)$ methyl)-5-mercapto-4H-1, 2, 4-triazol-4-yl\}-2-(2, 4-dichlorophenoxy)] acetamide

IR $(\mathrm{KBr}) \mathrm{cm}^{-1}: 3310(\mathrm{NH}), 3030-2910(\mathrm{C}-\mathrm{H}$ str., aromatic and aliphatic), $2550(\mathrm{SH})$ or 1165 $\mathrm{C}=\mathrm{S}, 1664(\mathrm{CO}$ of $\mathrm{CONH}), 1615(\mathrm{C}=\mathrm{N}), 1520(\mathrm{C}-\mathrm{N})$, 680(C- Cl), 855(trisubstituted benzene), ${ }^{1} \mathrm{HNMR}$ $\left(\mathrm{CDCl}_{3}\right)$ 8: 7.15-7.59 (m, 7H, Ar-H), $10.43(\mathrm{~s}, 1 \mathrm{H}$, $\mathrm{N}-\mathrm{H}), 8.12(1 \mathrm{H}, \mathrm{CONH}), \quad 4.64\left(\mathrm{~d}, 2 \mathrm{H}, \mathrm{S}-\mathrm{CH}_{2}\right)$.

6d N-[3-\{(1H-benzo[d]imidazol-2-ylthio) methyl)-5-mercapto-4H-1, 2, 4-triazol-4-yl\}-2-(4chlorophenoxy)] acetamide

IR (KBr) cm$)^{-1}: 3330(\mathrm{NH}), 3050-2910(\mathrm{C}-\mathrm{H}$ str., aromatic and aliphatic), $2535(\mathrm{SH})$ or 1173 $\mathrm{C}=\mathrm{S}, 1662(\mathrm{CO}$ of $\mathrm{CONH}), 1615(\mathrm{C}=\mathrm{N}), 1500(\mathrm{C}-\mathrm{N})$, 650(C- Cl), 835(p-disubstituted benzene), ${ }^{1} \mathrm{HNMR}$ $\left(\mathrm{CDCl}_{3}\right)$ ): 6.95-7.59 (m, 8H, Ar-H), $10.35(1 \mathrm{H}, \mathrm{N}-\mathrm{H})$, 8. $12(1 \mathrm{H}, \mathrm{CONH}), 4.65\left(2 \mathrm{H}, \mathrm{S}-\mathrm{CH}_{2}\right)$. 6e. $\mathrm{N}-[3-\{(1 \mathrm{H}-$ benzo[d]imidazol-2-ylthio $)$ methyl)-5-mercapto-4H-1, 2 ,4-triazol-4-yl\}-2-(4nitrophenoxy)]acetamide

IR (KBr) cm 1 : 3340(NH), 3050-2910 (C-H str., aromatic and aliphatic), $2535(\mathrm{SH})$ or 1173 $\mathrm{C}=\mathrm{S}, 1662(\mathrm{CO}$ of $\mathrm{CONH}), 1615(\mathrm{C}=\mathrm{N}), 1500(\mathrm{C}-\mathrm{N})$, 1515, 1355 ( $\mathrm{Ar}-\mathrm{NO}_{2}$ ), 840 (p-disubstituted benzene), ${ }^{1} \mathrm{HNMR}\left(\mathrm{CDCl}_{3}\right)$ ) $: 7.15-8.16(\mathrm{~m}, 8 \mathrm{H}, \mathrm{Ar}-\mathrm{H}), 10.45$ (s, $\mathrm{H}, \mathrm{N}-\mathrm{H}), 8.12(1 \mathrm{H}, \mathrm{CONH}), 4.42\left(\mathrm{~d}, 2 \mathrm{H}, \mathrm{S}-\mathrm{CH}_{2}\right)$.

6f.N-(3-((1H-benzo[d]imidazol-2-ylthio)methyl)5-mercapto-4H-1,2,4-triazol-4-yl)-2-(o-tolyloxy) acetamide

IR $(\mathrm{KBr}) \mathrm{cm}^{-1}: 3335(\mathrm{NH}), 3050-2910(\mathrm{C}-\mathrm{H}$ str., aromatic and aliphatic), $2535(\mathrm{SH})$ or $1165 \mathrm{C}=\mathrm{S}$, $1662(\mathrm{CO}$ of $\mathrm{CONH}), 1615(\mathrm{C}=\mathrm{N}), 1500(\mathrm{C}-\mathrm{N}), 840$ (o-disubstituted benzene), ${ }^{1} \mathrm{HNMR}\left(\mathrm{CDCl}_{3}\right) \delta$ : 6.88$7.56(\mathrm{~m}, 8 \mathrm{H}, \mathrm{Ar}-\mathrm{H}), 10.35(\mathrm{~s}, 1 \mathrm{H}, \mathrm{N}-\mathrm{H}), 8.12(1 \mathrm{H}$, $\mathrm{CONH}), 4.4\left(\mathrm{~d}, 2 \mathrm{H}, \mathrm{SCH}_{2}\right), 2.52\left(\mathrm{~s}, 3 \mathrm{H}, \mathrm{CH}_{3}\right)$.

6g.N-(3-((1H-benzo[d]imidazol-2-ylthio) methyl)5-mercapto-4H-1, 2, 4-triazol-4-yl)-2-(p-tolyloxy) acetamide

IR $(\mathrm{KBr}) \mathrm{cm}^{-1}: 3335(\mathrm{NH}), 3050-2910(\mathrm{C}-\mathrm{H}$ str., aromatic and aliphatic), $1165 \mathrm{C}=\mathrm{S}, 1662$ (CO of CONH), $1615(\mathrm{C}=\mathrm{N}), 1500(\mathrm{C}-\mathrm{N}), 845$ (p-disubstituted benzene), ${ }^{1} \mathrm{HNMR}\left(\mathrm{CDCl}_{3}\right)^{\prime}: 6.88-7.56(\mathrm{~m}, 8 \mathrm{H}, \mathrm{Ar}-\mathrm{H})$, 10. $55(\mathrm{~s}, 1 \mathrm{H}, \mathrm{N}-\mathrm{H}), 8.12(1 \mathrm{H}, \mathrm{CONH}), 4.64(2 \mathrm{H}$, $\left.\mathrm{S}-\mathrm{CH}_{2}\right), 2.52\left(\mathrm{~s}, 3 \mathrm{H}, \mathrm{CH}_{3}\right)$.

Table 1: Characteristic data of Synthesized compounds

\begin{tabular}{|c|c|c|c|c|c|c|c|}
\hline \multirow[t]{2}{*}{ Comp. } & \multirow{2}{*}{$\begin{array}{l}\text { m.p. } \\
{ }^{\circ} \mathrm{C}\end{array}$} & \multirow{2}{*}{$\begin{array}{l}\text { YIELD } \\
\text { (\%) }\end{array}$} & \multirow[t]{2}{*}{ M.F } & \multirow[t]{2}{*}{ M. Wt } & \multicolumn{3}{|c|}{ Elemental Analysis (\%) } \\
\hline & & & & & C & $\mathbf{H}$ & $\mathbf{N}$ \\
\hline $6 a$ & 172 & 88 & $\mathrm{C}_{18} \mathrm{H}_{16} \mathrm{O}_{2} \mathrm{~N}_{6} \mathrm{~S}_{2}$ & 412 & $\begin{array}{l}52.14 \\
(52.09)\end{array}$ & $\begin{array}{l}3.89 \\
(3.75)\end{array}$ & $\begin{array}{l}20.37 \\
(20.15)\end{array}$ \\
\hline $6 b$ & 278 & 72 & $\mathrm{C}_{18} \mathrm{H}_{15} \mathrm{O}_{2} \mathrm{~N}_{6} \mathrm{~S}_{2} \mathrm{Cl}$ & 446 & $\begin{array}{l}48.43 \\
(48.25)\end{array}$ & $\begin{array}{l}3.36 \\
(3.25)\end{array}$ & $\begin{array}{l}18.83 \\
(18.74)\end{array}$ \\
\hline $6 c$ & 276 & 70 & $\mathrm{C}_{18} \mathrm{H}_{14} \mathrm{O}_{2} \mathrm{~N}_{6} \mathrm{~S}_{2} \mathrm{Cl}_{2}$ & 480 & $\begin{array}{l}44.91 \\
(44.52)\end{array}$ & $\begin{array}{l}2.93 \\
(2.75)\end{array}$ & $\begin{array}{l}17.47 \\
(17.25)\end{array}$ \\
\hline $6 d$ & 269 & 69 & $\mathrm{C}_{18} \mathrm{H}_{15} \mathrm{O}_{2} \mathrm{~N}_{6} \mathrm{~S}_{2} \mathrm{Cl}$ & 446 & $\begin{array}{l}48.43 \\
(48.25)\end{array}$ & $\begin{array}{l}3.36 \\
(3.22)\end{array}$ & $\begin{array}{l}18.83 \\
(18.45)\end{array}$ \\
\hline $6 e$ & 278 & 80 & $\mathrm{C}_{18} \mathrm{H}_{15} \mathrm{~N}_{7} \mathrm{O}_{4} \mathrm{~S}_{2}$ & 457 & $\begin{array}{l}47.26 \\
(47.12)\end{array}$ & $\begin{array}{l}3.22 \\
(3.15)\end{array}$ & $\begin{array}{l}21.43 \\
(21.25)\end{array}$ \\
\hline $6 f$ & 273 & 72 & $\mathrm{C}_{19} \mathrm{H}_{18} \mathrm{O}_{2} \mathrm{~N}_{6} \mathrm{~S}_{2}$ & 426 & $\begin{array}{l}53.52 \\
(53.35)\end{array}$ & $\begin{array}{l}4.22 \\
(4.17)\end{array}$ & $\begin{array}{l}19.71 \\
(19.63)\end{array}$ \\
\hline $6 g$ & 265 & 70 & $\mathrm{C}_{19} \mathrm{H}_{18} \mathrm{O}_{2} \mathrm{~N}_{6} \mathrm{~S}_{2}$ & 426 & $\begin{array}{l}53.52 \\
(53.32)\end{array}$ & $\begin{array}{l}4.22 \\
(4.15)\end{array}$ & $\begin{array}{l}19.71 \\
(19.65)\end{array}$ \\
\hline
\end{tabular}




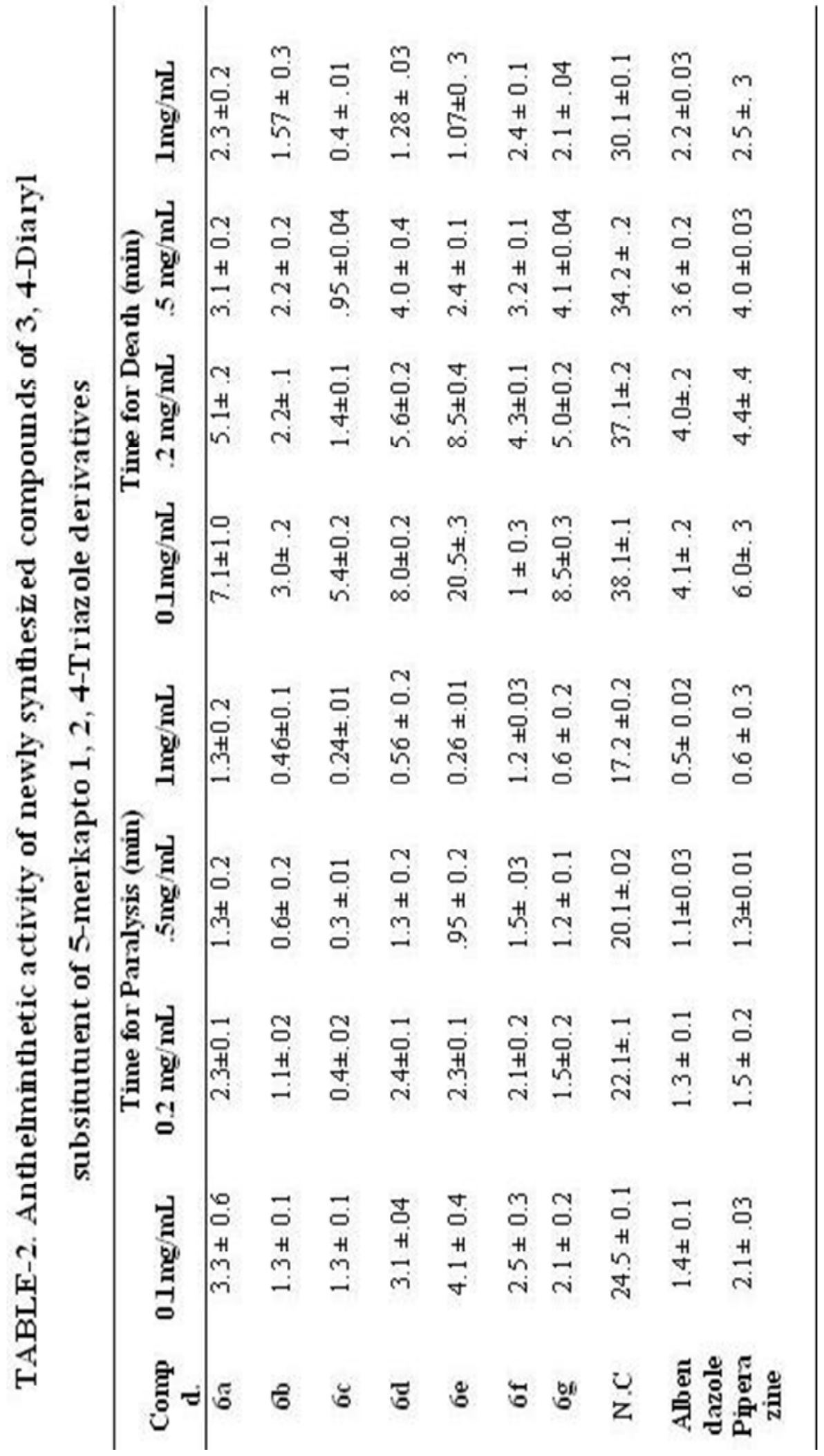




\section{RESULTS AND DISCUSSION}

The starting product 2-mercapto Benzimidazole prepared from o-phenylenediamine and potassium ethyl xanthate. The 2-mercapto benzimidazole was converted into the corresponding ehylchloroacetate and potassium carbonate which on esterification afforded ethyl 2-(1H-benzo[d] imidazol-2-ylthio)acetate (2). This in turn on treatment with hydrazine hydrate gave $2-(1 \mathrm{H}$ benzo[d]imidazol-2-ylthio) acetohydrazide (3) and was reacted with carbon disulphide in the presence of alcoholic potassium hydroxide to give of potassium 2-(2-(1H-benzo[d]imidazol-2ylthio) acetyl) hydrazinecarbodithioate (4). The finally product 4 and different aryloxyacetic acid hydrazides (5) were subjected to reflux and followed by acidification gave the product, which was purified by recrystallization from ethanol and the compounds were characterized as $\mathrm{N}-[3-\{(1 \mathrm{H}$-benzo[d]imidazol-2ylthio) methyl\}-5-mercapto-4H-1, 2, 4-triazol-4-yl]-2substituted phenoxy acetamide (6a-g). In IR Spectra $6 \mathrm{a}-6 \mathrm{~g}$ has been found to exhibit characteristic absorption bands (in $\mathrm{cm}^{-1}$ ) at : 3150(NH) 3050-2910 (C-H str., aromatic and aliphatic) $2550(\mathrm{SH})$ or 1150 $\mathrm{C}=\mathrm{S}, 1660(\mathrm{CO}$ of $\mathrm{CONH}), 1605(\mathrm{C}=\mathrm{N}), 1500(\mathrm{C}-\mathrm{N})$, 845(Substituted benzene), ${ }^{1} \mathrm{H}$ NMR spectrum of the compound (in $\mathrm{CDCl}_{3}$ ) has showed characteristic proton signals (in $\delta$, ppm) at : $2.3\left(\mathrm{~s} .3 \mathrm{H}, \mathrm{CH}_{3}\right)$, 4.6(s,2H, $\left.\left(\mathrm{OCH}_{2}\right)\right), 4.2\left(\mathrm{~d}, 2 \mathrm{H}, \mathrm{SCH}_{2}\right), 8.4(\mathrm{~d}, 1 \mathrm{H}, \mathrm{NH})$, 7.0-7.4(m,9H,Ar-H), 10.35(s,1H,NH), peak for $\mathrm{SH}$ not observed. Based on the spectral data, the compound $6 \mathrm{~g}$ was characterized as $\mathrm{N}-[3-\{(1 \mathrm{H}-$ benzo[d]imidazol-2-ylthio) methyl\}-5-mercapto-4H-1, 2, 4-triazol-4-yl]-2-(p-tolyloxy) acetamide and the elemental analyses of the compound is in conformity with the assigned structure. In similar manner seven 3, 4-diarylsubstituted-5-mercapto-1, 2, 4-triazoles (5) have been characterized in (Table-1). The anthelmintics evaluation of compounds $(6 \mathrm{a}-6 \mathrm{~g})$ in earth worms at four concentrations, i.e., 0.1, 0.2, 0.5 and $1 \mathrm{mg} / \mathrm{mL}$, is showed in (Table-2) along with experimental data on the drugs used as standards, albendazole and Piperazine citrate. A closer report of the data from the table indicates that compounds $6 \mathrm{~b}, 6 \mathrm{c}, 6 \mathrm{~d}$, and $6 \mathrm{e}$ have higher activity than other compounds, which was confirmed by their paralysis time of $0.46,0.24,0.56$ and 0.26 min, respectively, and death time of $1.57,0.39,1.28$ and $1.07 \mathrm{~min}$, respectively, at a concentration of 1 $\mathrm{mg} / \mathrm{mL}$. Compounds with presence of chlorine and nitro substituent at the ortho and para position of the phenyl ring $6 \mathrm{c}$ and $6 \mathrm{e}$ led to increase in activity. Chlorine at ortho position of the phenyl ring provided activity to compound $6 \mathrm{~b}$. The triazolyl ring clubbed with benzimidazole moiety in same molecule frame led to response in anthelmintic activity.

\section{CONCLUSION}

Present research work involves synthesis of some benzimidazole derivatives clubbed with triazolyl moiety and to explore their anthelminthetic activity. The compounds (6d, 6e) have been exhibited good anhelminthetic activity against earth worm due to presence triazolyl moiety with phenyl substituted electron withdrawing groups and conjugated with pharmacophore group such as benzimidazole ring in the same molecular structural frame.

\section{REFERENCES}

1. Rang, H. P., Dale, M. M., Ritter, J. M and Moore, P. K. Anthelmintic Drugs in Rang and Dale's Pharmacology, 5th ed., Churchill Livingstone, New York pp. 687-692 (2003).

2. Tripathi, K. D. Anthelmintics, Essential of Medical Pharmacology (Ed. M. Tripathy), 5th ed., Jaypee Brothers Medical Publishers (P) Ltd., New Delhi, 759-766 (2004).

3. Achar K.C., Hosamani K.M and Seetharamreddy H.R. Eur J. Med Chem., 45(5): 2048-54 (2010).
4. Sawhney S. N., Bhutani S. and Dharam Vir. Indian J. Chem., 26B: 348-350 (1987).

5. Valdez J., Cedillo R., Hernandez-Compos A., Yepez L., Hernandez-Luis F., NavarrteVazquez G., Tapia A., Cortes R., Hernandez $\mathrm{M}$ and Castillo R. Bioorg. Med. Chem. Lett. 12(16): 2221-4 (2002).

6. Clara R. Elisbeth B., Rebeca R., Marina R., Cristina V., Susana, S and Filomena M. J. Chem. Eng. Data., 57(2): 330-338 (2012).

7. Tonelli M., Simone M., Tasso B., Novelli F., 
Sparatore F.,Paglietti G., Pricl S., Giliberti G., Blois S., Ibba C., Sanna G., Loddo Rand La and Colla P. Bioorg Med. Chem., 18(18):297353(2010).

8. Bhriqu B., Siddiqui N., Pathak D., Alam M.S. Ali R and Azad B. Acta Pol Pharm., 69(1):5362(2012)

9. Nofal Z. M., Fahmy H.H and Mohamed H.S. Archives of pharmacal Research. 25(1):2838(2002).

10. Mohammed A. Al-Anber and H.M. Albishri, Orient J. Chem., 29(3): 905-909 (2012).

11. Bhat A.R., Varadarai Bhat $G$ and Gautham Shenoy G. Journal of Pharmacy and Pharmacology. 53(2):267-272(2002).

12. Emami S., Shoiapour S., Farmarzi M.A., Samadi N and Iranneiad H. Eur J. Med Chem., 66: 480-488(2013).

13. Dogdas E., Tozkoparan B., Kaynak F.B., Eriksson L., Kupeli E., Yesilada E and Ertan, M..Arzneimittelforschung. 57(4):196-202 (2007).
14. R. Soleymani, N. Niakan, S. Tayeb and K.G. Konandeh, Orient J. Chem., 28(2): 687-701 (2012).

15. Kochikyan T.V., Samvelyan M.A., Arutyunyan E.V., Arutyunyan V .S., Avetisyan A.A., Malakyan M.G., Vardevanyan L.A and Badzhinyan S.A. Pharmaceutical chemistry journal., 44(10):525-527(2011).

16. Hassan A., Ei-Sayed, Ahemed H, Moutafa, Ei-Fattah and Z.Haikal. Phosphorous, Sulfur and Silicon the related compounds. 188(5): 649-662(2013).

17. Olcay B., Bahittin K and Murat K. Turk J. Chem., 30:40(2006).

18. Mahendra R, Shiradkar, Mangesh Ghodake, Kailash, G., Bothara, Shashi, V,. Bhadari, Ana nikakje, Kalayan Chakravarthy, Akula. Nisheeth, Desai. Prashant J. Burange. Arkivoc, 15: 58-74(2007).

19. Kuppast I. J and Nayak, P. V. Indian J. Nat. Prod., 19:27-29(2003). 